\title{
Etnozoologi Masyarakat Pesisir Seruway Aceh Tamiang Dalam Konservasi Tungtong Laut (Batagur Borneoensis)
}

\author{
Setyoko*, Indriaty, Ruhama Desy, Ekariana S Pandia \\ *e-mail: setyoko@unsam.ac.id \\ Staff Pengajar Program Studi Pendidikan Biologi, FKIP, Universitas Samudra \\ Jalan Kampus Unsam, Meurandeh, Kota Langsa, Aceh, Indonesia - 24416
}

\begin{abstract}
Painted terrapin (Batagur borneoensis) is one of the reptiles found in the coastal area of Pusong Seruway Island, Aceh Tamiang Regency. Currently, the existence of wild population of painted terrapin is threatened to extinction due to factors of nature and community activities. The local government of Aceh Tamiang Regency has already protected painted terrapin (Batagur borneoensis) and listed it as protected species. This research is a descriptive exploratory survey to reveal the symptom and phenomenon of communities concerning their participation in the conservation of painted terrapin (Batagur borneoensis). Result of research was based on survey conducted in three villages with samples of 100 respondents given questionnaire through purposive random sampling technique. Data of ethnic communities consisted of; Tamiang, Aceh, Javanese, Batak and Arabic. Ethnozoology of communities obtained value local knowledge of communities as a form of awareness on animal protection included; participation in the sea turtle hatchling release, reduction in the exploitation activity of utilizing painted terrapin eggs (Batagur borneoensis) as srikaya (food) and traditional medicine, willingness not to take or disturb the animal and if they find painted terrapin (Batagur borneoensis), they will return the animal to its habitat or give it to the conservation team. A small part of the community joined in the assistance rescue group for painted terrapin (Batagur borneoensis).
\end{abstract}

Keywords: ethnozoology, conservation of painted terrapin (Batagur borneoensis).

\begin{abstract}
ABSTRAK
Tuntong Laut (Batagur borneoensis) merupakan salah satu jenis reptil yang ditemukan kawasan pesisir perairan pulau Pusong Seruway kabupeten Aceh Tamiang. Keberadaan populasinya di alam saat ini terancam punah, hal ini disebabkan oleh faktor alam dan faktor aktivitas masyarakat. Pemerintah daerah kabupaten Aceh Tamiang sudah melindungi Tuntong Laut (Batagur borneoensis), sebagai satwa yang dilindungi. Penelitian ini merupakan penelitian deskriptif yang bersifat survei eksploratif dengan mengungkapkan gejala dan fenomena masyarakat dalam pertisipasi konservasi Tuntong Laut (Batagur borneoensis). Hasil penelitian didasarkan survei di 3 desa dengan sampel 100 responden yang diberikan kuesioner dengan teknik purposive random sampling. Dataetnis masyarakat terdiri dari; Tamiang, Aceh, Jawa, Batak dan Arab. Etnozoologi masyarakat melalui nilai Kearifan lokal sebagai bentuk kesadaran akan perlindungan satwa antara lain; partisipasi dalam pelepasan Tukik,mengurangi aktifitas eksploitasi telur Tungtong Laut (Batagur borneoensis) sebagai srikaya dan obat tradisonal, tidak mengambil atau mengganggu satwa dan apabila masyarakat menemukan Tungtong laut (Batagur borneoensis), akan dikembalikan ke habitat atau diberikan ke tim pengelola konservasi. Masyarakat sebagain kecil tergabung dalam kelompok binaan penyelamatan Tuntong Laut (Batagur borneoensis),
\end{abstract}

Kata kunci: etnozoologi, konservasi. tuntong laut (Batugur borneoensis) 


\section{PENDAHULUAN}

Tungtong Laut (Batagur borneoensis)salah satu jenis kura-kura yang terancam punah, berdasarkan daftar CITES Appendiks II plus zero quota of wildcapture forcommercial trade(Ubaidillah, dkk. 2013; Guntoro, 2012):Persebaran Tungtong Laut (Batagur borneoensis)di Indonesia meliputi pulau kalimantan dan sumatera, salah satunyaditemukan dikawasan pesisir Seruway kabupeten Aceh Tamiang(Animaldiversity, 2016; Guntoro, 2012).

Pemerintah kabupaten Aceh Tamiang sudah melindungi Tungtong Laut (Batagur borneoensis) dan habitatnya, berdasarkan SK Bupati Nomor 63 Tahun 2014 dan PERDA Nomor 2 Tahun 2014(Aswita. 2014) Hasil survei tahun 2012 diperkirakan populasi Tungtong Laut (Batagur borneoensis)sekitar 141 individu.

Tungtong Kaut (Batagur borneoensis) memiliki morofologi Karapas panjang, jantan dewasa lebih kecil dari betina dengan ekor yang lebih panjang dan tebal. Ciri-ciri yang khas berupa alur-alur hitam yang terdiri atas garis lebar sebanyak 3 buah pada karapas. Perbandingan keping vertebral adalah keping pertama hingga ketiga dan keping 68 kelima lebar daripada panjangnya keping. Keping vertebral keempat lebih kecil dari pada keping vertebral ketiga. Panjang keping dada dengan urutan keping abdominal, femoral, pektoral, anal, humeral, gular. Jari kaki depan bercakar, sedangkan jari kaki belakang berselaput penuh. Pada individu anakan, terlihat adanya lunas (keel) pada keping vertebral. Lunas ini akan semakin menghilang seiring dengan meningkatnya umur. Saat musim musim kawin, bagian dorsum kepala individu jantan berwarna putih dengan keping frontal hingga nostrilnya berwarna merah. Tingkatan TaksonomiFilum: Chordata Kelas: Reptilia, Bangsa: Testudinata, Suku:
Geoemydidae, Marga: Batagur, Spesies: Batagur borneoensis (Schlegel dan Muller 1844). (Ubaidillah, dkk. 2013).

$$
\text { Tungtong Laut (Batagur }
$$

borneoensis)mendiami habitatperairan air tawar dan air payau.Tungtong Laut (Batagur borneoensis) semasa musim bertelur betina akan berenang keluar dari muara sungai untuk bertelur di pantai berpasir. Tungtong Laut (Batagur borneoensis) ukurannya mencapai lebih dari $62 \mathrm{~cm}$ dengan ukuran betina lebih besar dari jantan. Populasinya dialam liartelah lama terancampunah, hal ini disebabkan oleh faktor alam dan faktor aktivitas masyarakat(Ubaidillah, dkk. 2013).

Faktor alam yang menyebabkan berkurangnya jumlah populasi Tuntong laut (Batagur borneoensis) yaitu perubahan iklim dan penyakit, sementara faktor aktivitas masyarakat berhubungandengan pemanfaatan Tuntong laut(Batagur borneoensis) sepertiperburuandan pengambilan telur Tungtong Laut (Batagur borneoensis)oleh masyarakat untuk memenuhi kebutuhan nilai ekonomis(YSLI, 2013 dan Purwantono, 2015).Konservasi diupayakan oleh pemerintah daerah kabupaten Aceh Tamiang bekerjasama dengan Pertamina EP dan YSLImelakukan upaya konservasi Tungtong Laut (Batagur borneoensis)dengan melindungi habitat,penangkaran dan pelepasan tukik ke alam. Observasi dilapangan, masyarakat belumsepenuhnya mendukung upaya konservasi yang dilakukan pemeritah daerah kabupaten Aceh Tamiang, sebagian masyarakat pesisir Seruway masih melakukan aktifitas yang berkaitan pemanfaatan telur Tungtong Laut (Batagur borneoensis)bersifat eksploitatif sehingga menyebabkan penurunan jumlah populasi Tungtong laut (Batagur borneoensis).

Pemberian status perlindungan tidak cukup dalam mempertahankan 
populasiTungtong laut (Batagur borneoensis).Konservasiyang dilakukan pemerintah daerah harus segera didukungoleh elemen masyarakat pesisir Seruway.Hasil kajian etnozoologi masyarakat akan menggambarkan persepsi, pengetahuan, perlindungan dan partisipasimasyarakat dalam konservasiTungtong laut (Batagur borneoensis).

Etnozoologi meliputi pemanfaatan jenis satwa yang digunakan dalam berbagai kepentingan, seperti bahan pangan, kerajinan, pakaian, obat-obatan, hiasan, ritual, peralatan dan lainlainnya(Azrianingsih. 2011). Etnozoologi merupakan bagian dari bidang etnobiologi yang mempelajari tentang pengetahuan, pemanfaatan, pengelolaan satwa berkaitan dengan budaya masyarakat (Batoro, dkk. 2012).Etnobiologi metode analisis terdiri atas dua pendekatan yaitu emik (emic) dan etik (etic). Analisis emik adalah pendekatan yang mengacu pada kerangka sistem pengetahuan lokal dan etik adalah suatu analisis yang mengacu pada kerangka teoritis ilmiah (Oktaviani, dkk. 2013)

Kajian yang mempelajari hubungan antara satwa liar dan pemanfaatannya oleh kelompok masyarakat dikategorikan sebagai etnozoologi. Hubungan antara kebudayaan manusia dengan hewan dilingkungannya disebut etnozoologi(Faizah, dkk. 2012).Tujuan dari penelitian ini untuk mengetahuietnozoologi masyarakat pesisir Seruway di kabupaten Aceh Tamiang dalam mendukung program pemerintah daerah Kabupaten Aceh Tamiangdalam konservasi Tungtong laut(Batagur borneoensis).

\section{METODE PENELITIAN}

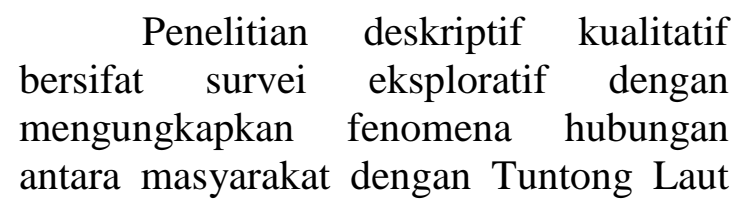

(Batagur borneoensis) dalampersepsi, pengetahuan, perlindungan dan partisipasi masyarakat dalam konservasi.

\section{Pelaksanaan Penelitian}

Penelitian di pesisir Seruway kabupaten Aceh Tamiang meliputi tiga desa yaitu Posung Kapal, Paya Udang, dan Kampung Baru. Waktu pelaksanaan penelitian pada bulan Septembersampai dengan November 2016.

\section{Pengumpulan Data}

Pengumpulan

datamelalui

pendekatan partisipasifdengan teknik purposive random sampling. Kuesioner yang diberikan kepada 100 responden yang tersebar di tiga desa. Kuesioner tersusun dari varibabel penelitian yang berkaitan dengan pengetahuan, persepsi, partisipasi dan perlindungan dan konservasi Tungtong Laut (Batagur borneoensis). Responden penelitian tidak dibatasi oleh pendidikan, perkerjaaan, ekonomi, jenis kelamin, dan usia.

\section{Analisis Data}

Analisis data deskriptif melalui proses mengevaluasi, mensintesis dan menarik kesimpulan. Data yang diolah dan dikodekan dalam bentuk angka menggunakan skala Liker skor ditafsirkan dan bentuk interpretasi tabulasi tabel, grafik atau histogram.

\section{HASIL DAN PEMBAHASAN}

Tungtong Laut (Batugur Borneoensis) di tiga desa yaitu Pusong Kapal, Paya Udang dan Kampung Baru kategori cukup dan rendah. Pengetahuan masyarakat mengenai Tungtong Laut (Batugur Borneoensis) untuk dilindungi masih rendah. Masyarakat mendapatkan informasi dari kegiatan pemerintah daerah kabupaten Aceh Tamiang dalam program kegiatan penyelematan telur dan pelepasan Tukik, sehingga sebagian besar masyarakat kurang mengetahui Tungtong Laut (Batugur Borneoensis) sudah dilindungi. Masyarakat lebih mengenal 
satwa ini sebagai "Tungtung" yang nerupakan jenis kura-kura yang hidup liar di pulau Pusong.

Pusong Kapal diperoleh profil masyarakat 5 etnis yang terdiri dari suku Tamiang 60\%, suku Aceh 17\%, suku Jawa 14\%, suku Batak 6\% dan Arab 2 $\%$. Profesi bidang pekerjaan pada masyarakat secara garis besar terdapat 4 kelompok yaitu Nelayan $77 \%$ merupakan pekerjaan yang paling umum dimasyarakat, Petani 3\%, Guru 11\% dan Pelajar 9\%. Sedangkan pendidikan masyarakat terbesar pada tingkat SD yaitu 52\%, SMP sebesar 14\%, SMA sebesar $23 \%$ dan S-1 sebesar $11 \%$, (Gambar 3.1). Etnozoologi masyarakat Pusong Kapal dalam pengetahuan $59,05 \%$, pertisipasi $54,52 \%$, persepsi $67,62 \%$, perlindungan $61,07 \%$ dan konservasi 43,69\% (Gambar 3.2).

Profil masyarakat 4 etnis yang terdiri dari suku Tamiang terbesr yaitu $78 \%$, suku Aceh sebesar 4\%, suku Jawa sebesar $11 \%$, suku Batak sebesar $7 \%$. Profesi bidang pekerjaan pada masyarakat secara garis besar terdapat 3
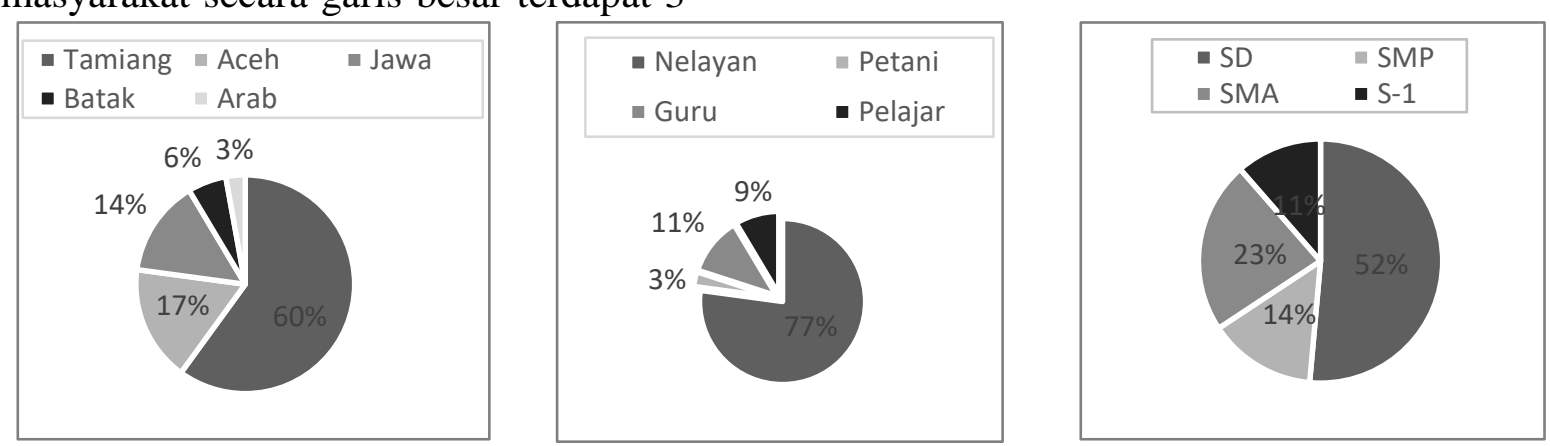

Gambar 3.1. Profil etnis, pekerjaan dan pendidikan masyarakat Pusong Kapal

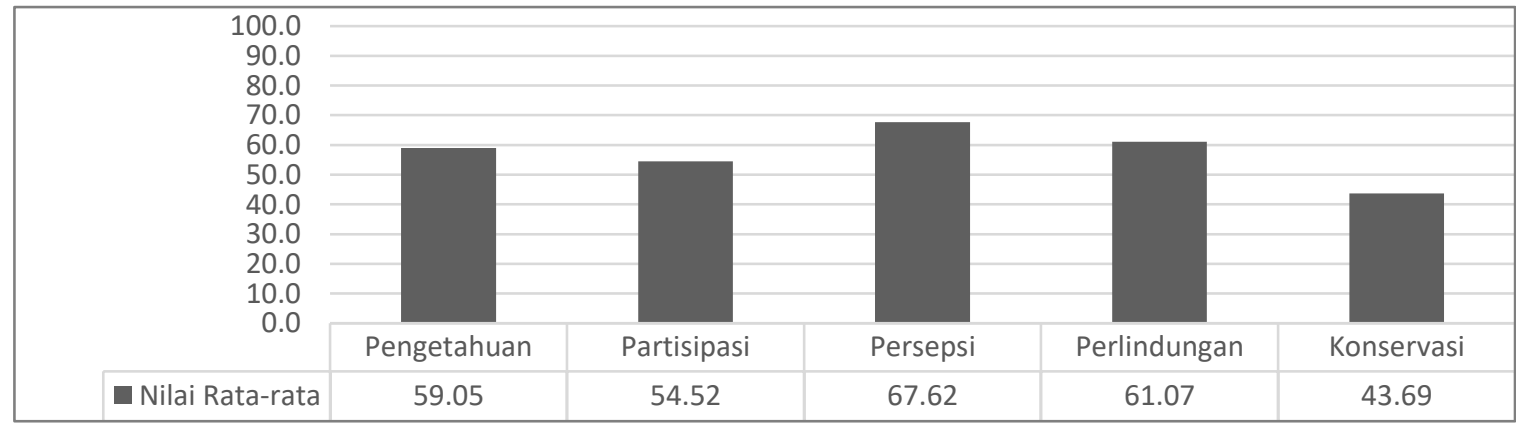

Gambar 3.2. Etnozoologi masyarakat Pusong Kapal dalam Konservasi Tungtong Laut (Batugur Borneoensis) kelompok yaitu Nelayan 58\% merupakan pekerjaan yang paling umum dimasyarakat, Petani $13 \%$, sisanya ibuibu rumah tangga $29 \%$. pendidikan masyarakat terbesar pada tingkat SD yaitu 78\%, SMP 13\%, SMA 7\% dan S-1 2\% (Gambar3.3). Etnozoologi masyarakat di desa Paya Udang dengan pengetahuan $30,30 \%$, partisipasi $43,1 \%$, persepsi $52,4 \%$, perlindungan $28,8 \%$ dan konservasi 37,7\% (Gambar 3.4).

Profil masyarakat 3 etnis yang terdiri dari suku Tamiang terbesar yaitu 62\%, suku Aceh 25\%, suku Jawa 13\%. Profesi bidang pekerjaan pada masyarakat secara garis besar terdapat 3 kelompok yaitu Nelayan $75 \%$ merupakan pekerjaan paling umum di masyarakat, Wiraswasta $12 \%$, sisanya pelajar $13 \%$. Pendidikan masyarakat terbesar pada tingkat SD yaitu 50\%, SMP 25\%, SMA 25\% (Gambar3.5). Etnozoologi masyarakat kampung Baru pengetahuan $43,80 \%$, pertisipasi $45,8 \%$, persepsi $60,9 \%$, perlindungan $41,7 \%$ dan Konservasi 40,1\% (Gambar 3.6) 

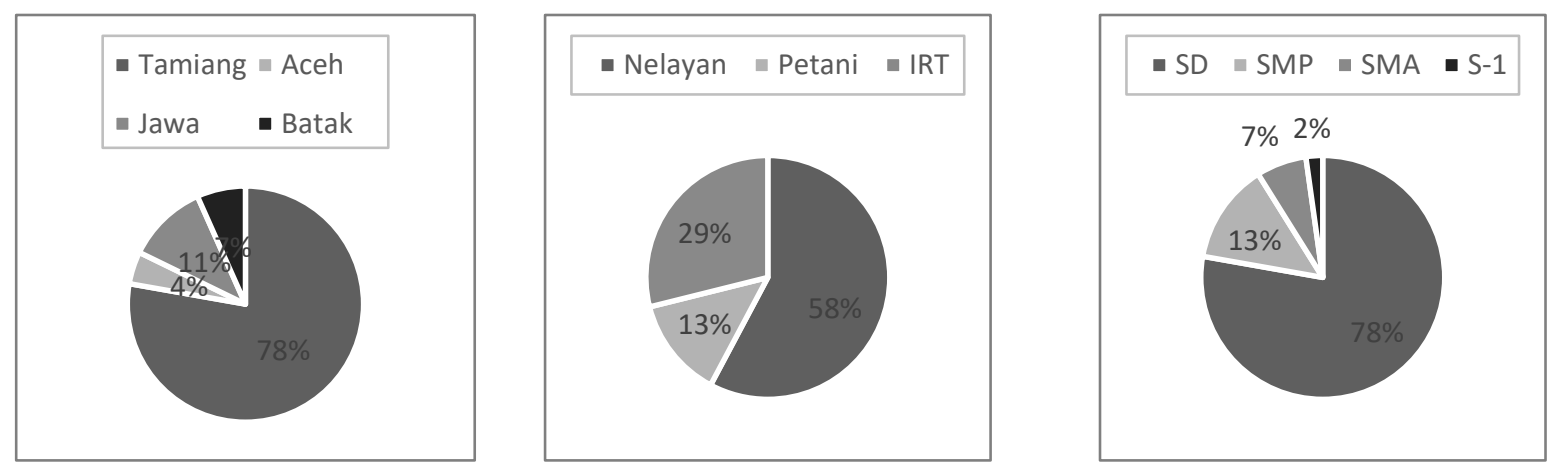

Gambar 3.3 Profil etnis, pekerjaan dan pendidikan masyarakat Paya Udang

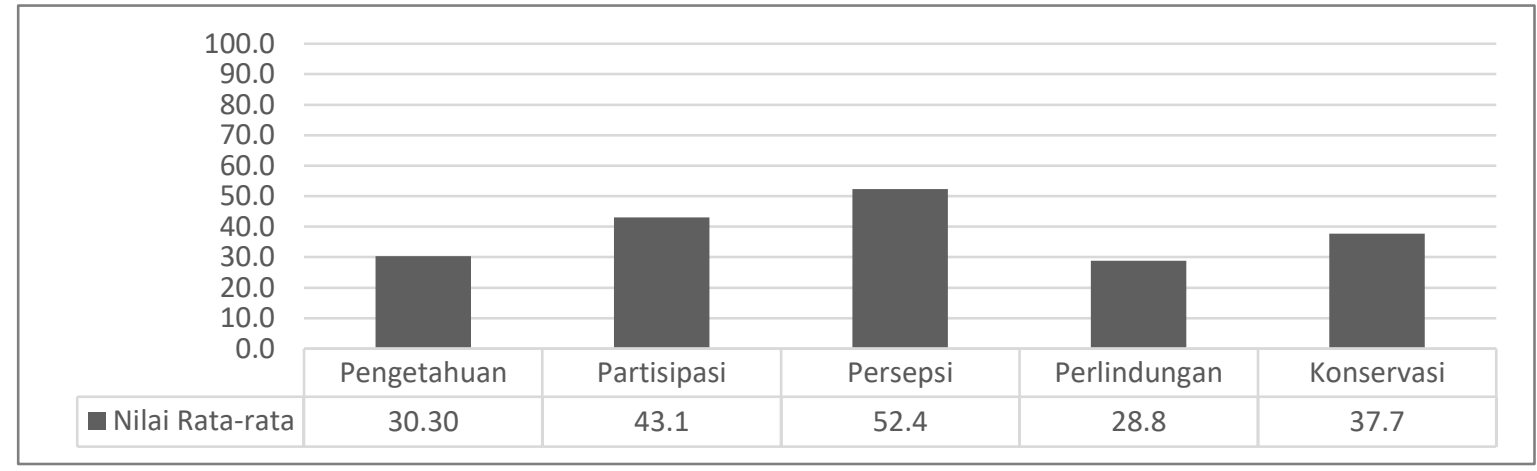

Gambar 3.4. Etnozoologi masyarakat Paya Udang dalam Konservasi Tungtong Laut (Batugur Borneoensis)
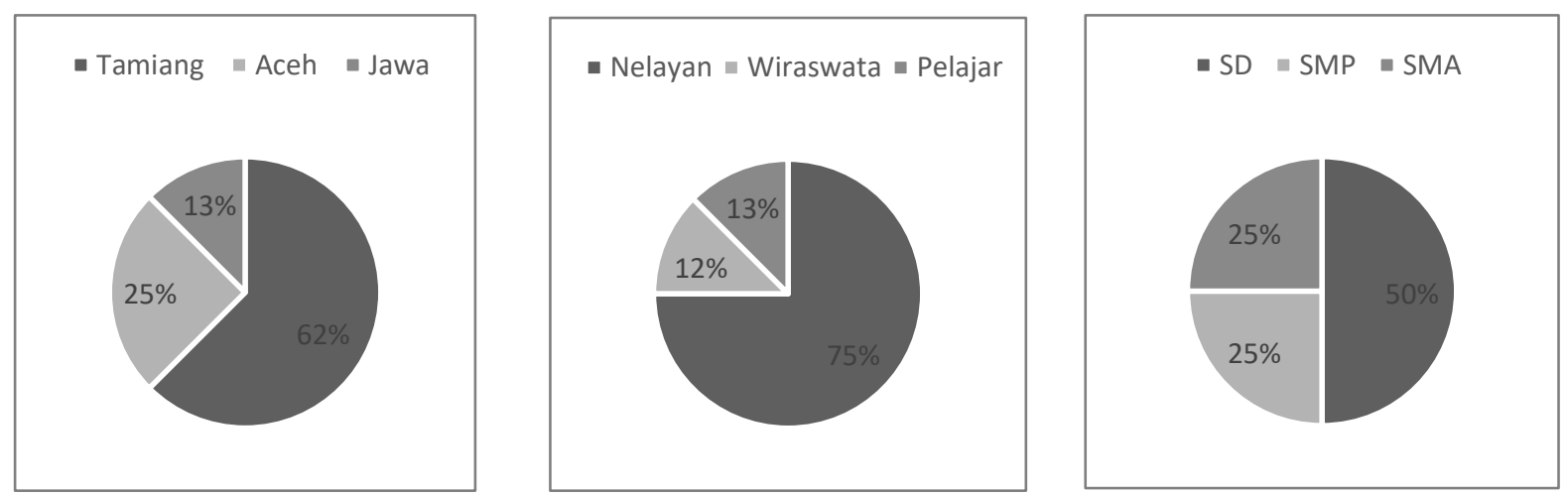

Gambar 3.5. Profil etnis, pekerjaan dan pendidikan masyarakat Kampung Baru

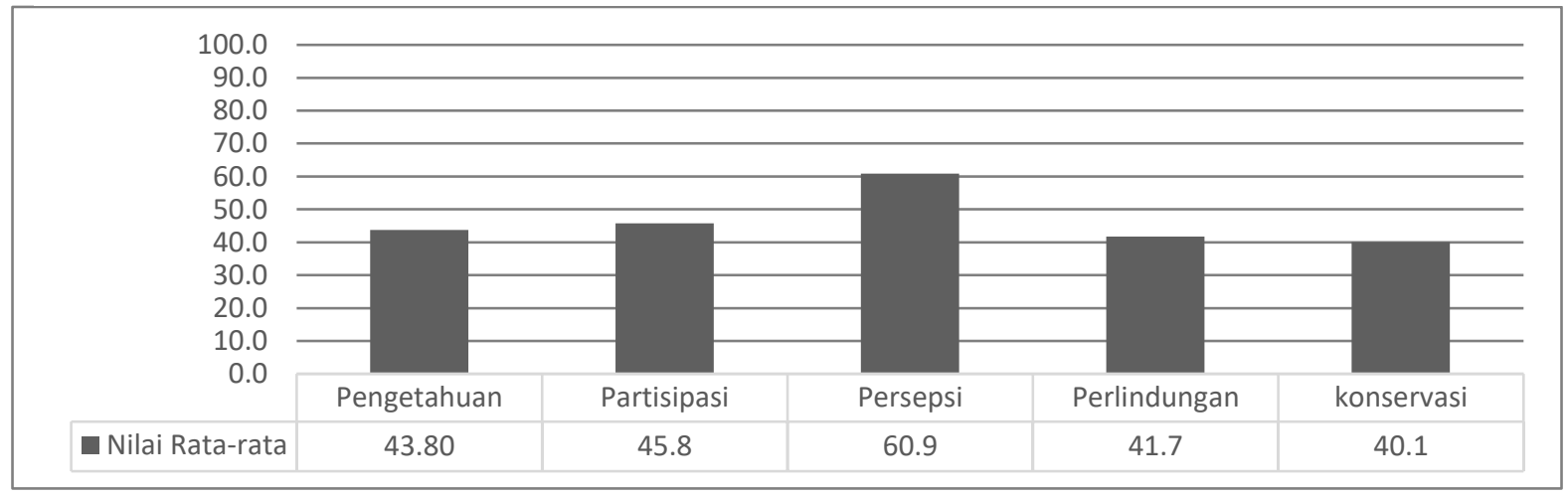

Gambar 3.6 Etnozoologi masyarakat Kampung Baru dalam Konservasi Tungtong Laut (Batugur Borneoensis) 
Konservasi merupakan suatu upaya yang dilakukan untuk menjamin keberlangsungan dan kelestarian populasi suatu jenis satwa dalam habitatnya(Dermawan, dkk 2012). Etnozoologi masyarakat pesisir Seruway dalam persepsi, pengetahuan, partisipasi, perlindungan dan konservasi terhadap Tuntong Laut (Batagur Borneonsis), diperoleh hasil data dari sebaran kuesioner yang diberikan kepada responden yaitu masyarakat di pesisir Seruway yang meliputi 3 desa yaitu Paya Udang, Kampung Baru dan Pusong Kapal. Faktor-faktor lainnya yang mempengaruhi pengetahuan masyarakat mengenai Tungtong Laut (Batugur borneoensis) yang dilindungi Pemerintah Daerah disebabkan rendahnya pendidikan masyarakat. Profil pendidikan masyarakat di tiga desa pesisir Seruway hampir rata-rata dijenjang tamatan Sekolah Dasar (SD) sebagian kecil dari tingkat Sekolah menengah Atas (SMA) dan Sarjana (S1). Asri dan Bagyo (2015),pengetahuan dipengaruhi oleh beberapa faktor antara lain; pendidikan, pengalaman, usia, dan informasi. Pada umumnya semakin tinggi tingkat pendidikan seseorang, maka semakin baik pengetahuannya. Tingkat pengetahuan seseorang dipengaruhi oleh tingkat pendidikan, keaktifan mengikuti informasi media massa, dan berorganisasi(Setyawan, dkk 2015).

Partisipasi masyarakat rendah di tiga desa, ini disebabkan masih belum tergeraknya keinginan dari masyarakat untuk berupaya ikut dalam konservasi. Optimalisasi pemanfaatan sumber daya alam merupakan kegiatan yang sulit penangannya, karena berkaitan antara manusia, kebijakan dan kepentingan hidupan satwa liar (Semiadi, 2007). Persepsi masyarakat masuk dalam kategori cukup, hal ini dampak positif dari kegiatan tahunan yaitu pelepasan Tukik, sehingga masyarakat cukupmemahami manfaat terhadap Tungtong Laut (Batugur Borneoensis). Strategi pendidikan konservasi kepada masyarakat melalui sosialisasi, dan diskusi pada seluruh lapisan elemen masyarakat rumah tangga sampai perguruan tinggi(Dermawan, dkk, 2012). Kegiatan konservasi belum melibatkan elemen masyarakat di pesisir Seruway. Masyarakat terlibat hanya sebagian kecil yang melaksanakan kegiatan konservasi yaitu masyarakat yang tergabung dalam keanggotaan aktif tim binaan LSM YSLI dan pengurus perangkat desa. Masyarakat khususnya pekerjaan sebagai nelayan, mereka tidak ikut terlibat secara langsung dalam kegiatan konservasi. Sebagian besar nelayan tidak mengetahui peraturan dan larangan yang dibuat pemerintah daerah dalam konservasi. Kegagalan program konservasi disebabkan kesadaran hukum yang belum mencapai batas minimum, tekanan terhadap habitat yang terus bertambah, meningkatknya aktifitas manusia (Semiadi, 2007).

Perlindungan masyarakat

terhadap Tungtong Laut (Batugur Borneoensis) di dua desa dengan kategori sangat rendah dan di satu desa dengan kategori cukup. Masyarakat yang bekerja sebagai nelayan secara langsung berinteraksi dengan habitat Tungtong Laut (Batugur Borneoensis) di pulau Pusong. Habitat secara langsung dilewati sebagai akses jalur transportasi oleh para nelayan dalam mencari ikan dilaut. Hasil wawancara responden di tiga desa bahwa masyarakat sebagian kecilmemanfaatkan telur Tuntong Laut (Batugur borneoensis) sebagai srikaya (bahasa daerah dikenal dengan istilah Tengguli) merupakan makanan tradisional masyarakat dibuat dari bahan dasar telur Tungtong Laut (Batugur borneoensis).

Pemanfaatan satwa liar telah dilakukan oleh berbagai etnis di dunia sejak dulu untuk memenuhi kebutuhan 
hidup, antara lain sebagai sumber bahan makanan dan obat(Novrianti, dkk 2014). Jumlah Tungtong Laut (Batugur Borneoensis) sangat banyak, hewan ini bebas berkeliaran di sekitar pulau Pusong sekitar 10 tahun silam, saat ini jumlahnya sudah semakin sedikit dibandingkan pada 3 tahun terkahir. Masyarakat pesisir Seruway mendapatkan telur dari Pulau Pusong habitat asli dari Tungtong Laut (Batugur borneoensis) pada saat musim bertelur pada bulan Oktober sampai Desember secara tertutup dari tim konservasi.

Masyarakat juga menggunakan telur sebagai obat tradisional yang dipercaya oleh masayarakat sebagai obat penambah stamina bagi pria dan obat panas dalam. Masyarakat pribumi di belahan benua Asia menggunakan satwa liar sebagai pengobatan tradisional dengan tujuan mengobati berbagai penyakit dan masalah kesehatan lainnya (Zubaidah, dkk 2012).Masyarakat dayak dikalimantan memanafaatkan berbagai hasil alam untuk keperluan sehari-hari. Salah satu bagian dari alam yang dimanfaatkan adalah berbagai jenis hewan, biasanya masyarakat menggunakan hewan untuk pemenuhan protein (dikonsumsi), keperluan adat, pengobatan, supranatural dan komersial ekonomi (Epilurahman, dkk 2012).Eksploitasi yang terjadi terusmenerus tanpa menerapkan prinsip kelestarian akan mengancam populasi reptil dialam(Arisnagara, 2009)

Kearifan lokal masyarakat di pesisir Seruway saat ini sudah mulai tergerak melakukan kegiatan konservasi Tungtong Laut (Batugur Borneoensis). Masyarakat yang bekerja sebagai nelayan apabila menemukan satwa Tungtong Laut (Batugur borneoensis) akan dibawa pulang dan dikembalikan kepada tim pengelola konservasi, awalnya masyarakat meminta imbalan kepada tim pengelola konservasi berupa uang dengan sistem pertukaran imbalan (barter) 1 ekor Tungtong Laut (Batugur Borneoensis) akan dihargai Rp.100.000 Rp.200.000 dan 1 butir telur dhargai Rp.20.000.

Kearifan masyarakat lokal dalam pemanfaatan sumber daya alamnya, semakin terkikis oleh himpitan kebutuhan hidup, sehingga tidak sedikit masyarakat membuang prinsip konservasi tradisional (Arisnagara, 2009). Etnozoologi yang spesifik pada setiap daerah akan hilang bersamaan hilangnya sumber daya alam. Hasil wawancara dengan responden menyatakan bahwa dahulu ada fenomena budaya syukuran laut yang dilakukan oleh masyarakat yang sudah mulai hilang. Syukuran laut dalam istilah kebudayaan suku Aceh digelar untuk menandai dimulainya musim melaut para nelayan (Apriyana, 2015). Masyarakat berterimakasih kepada Tuhan Yang Maha Esa dengan mengharap hasil laut yang melimpah dan mengambil ikan dilaut yang bisa dikonsumsi, diartikan bahwa masyarakat tidak mengambil satwa lain yang tidak bisa dikonsumsi.

Perkembangan akhir tahun 2016 selama penelitian, sebagian elemen masyarakat sudah tidak mengharapkan uang. Masyarakat yang menemukan Tungtong Laut (Batugur Borneoensis)dibiarkan hidup atau dikembalikan ke pulau Pusong dan sebagian dibawa pulang untuk diberikan kepada tim pengelola konservasi. Berkurangnya perdagangan jual dan beli telur Tungtong Laut (Batugur Borneoensis)pada saat musim bertelur yang dijadikan masyarakat sebagai Srikaya (makanan), hal ini terlihat tidak ada bentuk transaksi jual beli di masyarakat telur Tungtong Laut (Batugur Borneoensis).

Kegiatan konservasi yang diupayakan dengan memberikan kesadaran kepada masyarakat menguatkan nilai kearifan lokal. 
Masyarakat secara sadar sudah tergabung dalam anggota kelompok binaan penyelamatan Tuntong Laut (Batugur borneoensis). Tindakan konservasi satwa dapat dilakukan dengan baik melalui pendekatan kearifan tradisional yang ada di wilayah tersebut(Aris dan Bagyo, 2015). Harapan sebagian besar masyarakat pesisir Seruway, daerahnya bisa dijadikan sebagai ikon wisata konservasi di kabupaten Aceh Tamiang, sehingga dapat menumbuhkan ekonomi masyarakat dimasa mendatang. Pemerintah Daerah kabupaten Aceh Tamiang mengupayakan dorongan nilai kearifan masyarakat yang diintergasikan dengan kebijakan konservasi, sehingga semakin tingginya peran masyarakat dalam mendukung program konservasi Tungtong Laut (Batagur borneoensis).

\section{KESIMPULAN}

Etnozoologi masyarakat di tiga desa meliputi pengetahuan, partisipasi persepsi, perlindungan dan konservasi masih berada dalam interval cukup (60 $69 \%$ ) dan rendah (50 -59\%). Kearifan lokal masyarakat, menurunnyakeinginanan mengambil telur Tungtong Laut (Batagur borneoensis),masyarakat mulai bergabung dengan kelompok binaan penyelamatan Tuntong Laut (Batagur borneoensis), dan kesadaran dalam pelestarian Tungtong Laut (Batagur borneoensis).

\section{Ucapan Terimakasih}

Ucapan terimakasih penulis haturkan kepada LPPM dan PM Universitas Samudra dan seluruh Civitas Akademika Universitas Samudra serta pihak terkait yang telah memberikan dana penelitian ataupun bantuan lainnya dalam program Hibah skema Penelitian Dosen Muda Universitas Samudra Tahun 2016.
DAFTAR PUSTAKA

Apriyana. 2015. Kearifan lokal masyarakat aceh dalam konservasi laut. Jurnal Biologi Edukasi. Vol. 7. No. 1

Arisnagara. 2009. Pemanfaatan reptil sebagai obat dan makanan di daerah khusus ibu kota (DKI) jakarta. Konservasi sumberdaya hutan dan ekowisata Fakultas Kehutanan.IPB. Bogor.

Asri dan Bagyo. 2015. Persepsi Masyarakat Terhadap Ular Sebagai Upaya Konservasi Satwa Liar Pada Masyarakat Dusun Kopendukuh, Desa Grogol, Kecamatan Giri, Kabupaten Banyuwangi. Jurnal PAL. Vol 6. No. 1

Aswita. 2014. Sustainability of Integrated Coastal Management in Pusong Cium Island for Habitat ofTuntongLaut (Batagurborneoensis).

Presentation On Rufford Conference in Sabang. Lembaga Pusat Penelitian dan Pengabdian Masyarakat, Sekolah Tinggi Kehutanan Banda Aceh, Januari. 2014.

Azrianingsih. 2011. Etnobiologi masyarakat tengger di bromo tengger semeru Jawa timur. Laporan Penelitian Hibah Bersaing. Universitas Brawijaya.

Batoro, dkk. 2012. Pengetahuan Fauna (Etnozoologi) Masyarakat Tengger di Bromo Tengger semeruJawa Timur. JumaJ llmiah llmu-ilmu Hayati. Biota Vol. 17. No. 1: 45-54.

Dermawan,dkk 2012. Pedoman teknis pengelolaan konservasi penyu. Direktorat Konservasi dan Taman Nasional Laut, Direktorat Jenderal Kelautan, Pesisir dan Pulau-Pulau Kecil, Departemen Kelautan dan Perikanan RI 
Eprilurahman, dkk. 2012. Sekilas Etnozoologi Masyarakat Dayak di Kalimantan. Flora dan Fauna Kalimantan: Dokumentasi Hasil Tim Peneliti Ekspedisi Khatuliswa. Universitas Gajdah Mada.

Faizah, dkk. 2012. etnozoologi dalam pembelajaran taksonomi vertebrata di jurusan biologi fmipa unesa. jurnal biologi unesa.

Geografic of Painted Terrapin (Batagur borneoensis)(http:/animaldiversit y.org), diakses 7 April 2016

Guntoro, J. 2012. The Body Size and Some Field Notes of Painted Terrapin (Batagur borneoensis) in District of Aceh Tamiang, Indonesia. Asian Journal of Conservation Biology, (Online) Vol. 1 No. 2, pp. $74 \quad-77$ (http://www.ajcb.in), diakses 7 April 2016.

Laporan Pembesaran Tukik Tuntung Laut (Batagur Borneoensis) Dalam rangka Kegiatan pelestarian tuntung laut di aceh tamiang. 2013. Yayasan Satucita Lestari Indonesia (YSLI) dan PT Pertamina EP Field Rantau. Kuala Simpang, Aceh.

Novriyanti, dkk. 2014. Pola dan nilai Lokal Etnis dalam Pemanfaatan Satwa pada Orang Rimba Bukit Duabelas Provinsi Jambi. Jurnal penelitian hutan dan konservasi alam. Vol. 11. No. 3

Oktaviani, dkk. 2013.Etnozoologi, Biologi Reproduksi, Dan Pelestarian Ikan Lema Rastrelliger Kanagurta (Cuvier, 1816) Di Teluk Mayalibit
Kabupaten Raja Ampat Papua Barat Indonesia. Disertasi: Universitas Indonesia

Purwantono. 2015. Penangkaran kurakura yang berkelanjutan berdasarkan model sistem dinamik. Diterbitkan oleh: Sekolah Pascasarjana Institut Pertanian Bogor: Bogor

Rahajeng, dkk. 2014. Pengetahuan, Persepsi dan Partisipasi Masyarakat dalam Konservasi di Kawasan Cagar Alam Pulau Sempu Kabupaten Malang. Management of aquatic resources. Vol. 3 No. 4.

Semiadi. 2007. Pemanfaatan Satwa Liar dalam Rangka Konservasi dan Pemenuhan Gizi Masyarakat. Jurnal Zoo Indonesia. Vol 16.No.2

Setyawan, dkk. 2015. Kajian Etnozoologi Masyarakat Desa Hadiwaarno Kabupaten Pacitan dalam Konservasi Penyu Sebagai bahan Penyusunan Booklet Penyuluhan Masyarakat. Jurnal pendidikan biologi indonesia. Vol 1. No. 3.

Ubaidillah, dkk. 2013. Biota Perairan Tenacam Punah Indonesia: Perioritas Perlindungan. Jakarta: Direktorat Konservasi Kawasan dan Jenis Ikan, Ditjen Kelautan, Pesisir, dan Pulau Kecil Kementerian Kelautan dan Perikanan

Zubaidah, dkk. 2012. Kajian: Penggunaan hewan bagi Perobatan Tradisional dalam Kalangan Masyarakat Pribumi di Asia. Malaysia journal of society. Vol 8 No 3 